\title{
GUM CHEWING DECREASES THE DURATION OF POSTOPERATIVE ILEUS AFTER ILEOSTOMY REVERSAL: A SINGLE CENTER EXPERIENCE.
}

1. MBBS, FCPS (Surgery) Medical Officer DHQ Hospital, Chiniot.

2. MBBS, FCPS

Assistant Professor Surgery PMC, Faisalabad.

3. MBBS, FCPS, FACS Associate Professor Surgery CMH Lahore Medical College, Lahore.

4. BSc, MBBS, FCPS (Surgery) Registrar International Training Fellow Colorectal Surgery Heartlands Hospitals University Hospitals

Birmingham Nhs Trust.

5. MBBS, FCPS (Surgery) Medical Officer DHQ, MBDIN

6. MBBS, FCPS (Surgery) WMO Surgery

Allied Hospital, Faisalabad.

Correspondence Address: Dr. Muhammad Kamran DHQ Hospital, Chiniot

kamran238.mks@gmail.com

Article received on: 17/06/2019

Accepted for publication: 10/10/2019

\section{INTRODUCTION}

Enteric fever can be fatal for all age groups, with a global mortality rate of about $20 \%$ if no effective treatment is done, which falls to about $3 \%$ of active and effective management is done. Most of the patients having enteric fever have acute or chronic complications, but exact incidence varies among age groups and populations. Most serious complication is Typhoid intestinal perforation (TIP). The incidence of enteric perforation is about $20 \%$ to $40 \%$ patients. ${ }^{1}$ The procedure done in patients with enteric perforation is lleostomy, i.e opening the small gut on the abdominal wall, which is a safe practice among patients having peritonitis. $^{2}$

Most often ileostomy is done for temporary reasons; aim of which is reversal within 3 months but varies a lot from hospitals-to-hospitals, as it is simple, short but needs skills. ${ }^{3}$ It often requires dissection of adhesions and bowel mobilization. ${ }^{4}$ Gl disturbance including ileus can lead to serious discomfort and increase morbidity after the procedure. $^{5}$ Generally, this postoperative gastrointestinal dysfunction improves by decompressing the stomach and stopping oral diet along with IV fluids until conditions is improved. ${ }^{6}$ Recently, many studies on gum chewing during the post-operative period have shown improvement in postoperative gastrointestinal dysfunction. ${ }^{7}$

The concept of gum chewing was introduced in 2002 and was proven to be helpful in ileus patients due to gastric stimulation. ${ }^{8}$ Sham feedings promotes digestion through vagal stimulation and hormones secretions in the gut. ${ }^{9}$ Gum chewing is a more convenient method of stimulation. ${ }^{8}$ Results of different studies show controversy regarding the use of post-operative 
gum chewing in terms of length of hospital stay and time of passage of first flatus.

As, there is no local data available I designed this study to assess a better method with short length of hospital stay, lesser time of passage of first flatus and lesser time of appearance of bowel sound that will be offered to the patients in future.

\section{MATERIAL \& METHODS}

Patients of 20 to 60 years old undergoing elective surgery for typhoid ileal perforation were included after informed consent in this trial done Allied Hospital Faisalabad after approval from the ethical committee.

Typhoid ileal perforation was defined on clinical grounds with fever (axillary temperature > 99.6 starts low and increases daily) with headache, muscle aches, loss of appetite, abdominal pain and peritonitis (abdominal tenderness with difficulty in flatus), along with radiological grounds (x-ray abdomen erect showing airunder-diaphragm or intra-peritoneal fluid seen on abdominal sonography). Length of hospital stay was defined in days (from the date of surgery till discharge).

Discharge criteria was defined as patient having stable vitals with no fever, tolerating solid food without nausea or vomiting, operation pain controlled with no obvious complications, and can follow routine alone or with attendant care. Time of passage of first flatus was measured from time of completion of surgery to the time when the patient passes intestinal gas after surgery. It was based on history from the patient.

Patients with inflammatory bowel disease, abdominal radiation exposure, pregnant females, those admitted in ICU for $>24 \mathrm{hrs}$ postoperatively were excluded from study.

Sample size of 60 calculated using WHO sample size calculator for 2 mean, test value of population mean $=7.63^{10}$, anticipated population mean $=9.47^{10}$ with pooled deviation $=2.15$ power of study $80 \%$ and level of significance $=80 \%$. Objective was explained to all and Two groups with $A$ : allocated to chewing gum three times a day up to discharge; Control group: allocated to standard post-operative care without chew gum. Length of hospital stay and time of passage of first flatus was noted.

Data was recorded on predesigned performa. Data was analyzed using SPSS 21. Descriptive statistics like mean and standard deviation was calculated for variables like age, length of hospital stay and time of passage of first flatus. Frequency was calculated for qualitative variables like gender. Independent sample t-test was used to compare length of hospital stay, time of passage of first flatus between two groups. $P$ value $<0.05$ was taken as significant. Effect modifiers like age and gender was controlled by stratification. Post stratification independent sample t-test was applied.

\section{RESULTS}

60 patients (30 in chewing gum group and 30 in control group) were included in the study strictly following the inclusion and the exclusion criteria to compare post-operative gum chewing with standard post-operative care in patients undergoing elective surgery for ileostomy closure after perforation in terms of mean length of hospital stay and mean time of passage of first flatus.

Age distribution showed that $53.33 \%(n=16)$ in Chewing gum group and $50 \%(n=15)$ in Control group were between 20-40 years of age whereas $46.67 \%(n=14)$ in Chewing gum group and $50 \%(n=15)$ in Control group were between 4160 years of age, mean+sd was calculated as $39.1+8.57$ years in Chewing gum group and $40.63+9.40$ years in Control group. (Table-I)

\begin{tabular}{|l|c|c|c|c|}
\hline \multirow{2}{*}{$\begin{array}{c}\text { Age (in } \\
\text { Years) }\end{array}$} & \multicolumn{2}{|c|}{$\begin{array}{c}\text { Chewing Gum } \\
\text { Group(n=30) }\end{array}$} & \multicolumn{2}{|c|}{$\begin{array}{c}\text { Control } \\
\text { Group(n=30) }\end{array}$} \\
\cline { 2 - 6 } & $\mathbf{n}$ & $\%$ & $\mathbf{n}$ & $\%$ \\
\hline $20-40$ & 16 & 53.33 & 15 & 50 \\
\hline $41-60$ & 14 & 46.67 & 15 & 50 \\
\hline Total & 30 & 100 & 30 & 100 \\
\hline & Table-I. Age distribution (n=60) \\
\hline
\end{tabular}


Gender distribution of the patients was done, it shows that $56.67 \%(n=17)$ in Chewing gum group and $53.33 \%(n=16)$ in Control group were male cases whereas $43.33 \%(n=13)$ in Chewing gum group and $46.67 \%(n=14)$ in Control group females. (Table-II)

\begin{tabular}{|l|c|c|c|c|}
\hline \multirow{2}{*}{ Gender } & \multicolumn{2}{c|}{$\begin{array}{c}\text { Chewing Gum } \\
\text { Group }\end{array}$} & \multicolumn{2}{c|}{$\begin{array}{c}\text { Control Group } \\
(\mathbf{n = 3 0 )}\end{array}$} \\
\cline { 2 - 6 } & $\mathbf{n}$ & $\%$ & $\mathbf{n}$ & $\%$ \\
\hline Male & 17 & 56.67 & 16 & 53.33 \\
\hline Female & 13 & 43.33 & 14 & 46.67 \\
\hline Total & 30 & 100 & 30 & 100 \\
\hline
\end{tabular}

Mean length of hospital stay in Chewing gum group was $7.73+0.74$ days and $10.27+0.87$ days in Control group, p value was 0.0001. (Table-III)

\begin{tabular}{|c|c|c|c|c|}
\hline $\begin{array}{c}\text { Length of } \\
\text { Hospital } \\
\text { Stay (in } \\
\text { days) }\end{array}$ & \multicolumn{2}{|c|}{$\begin{array}{c}\text { Chewing Gum } \\
\text { Group }(\mathbf{n = 3 0 )}\end{array}$} & \multicolumn{2}{|c|}{$\begin{array}{c}\text { Control Group } \\
(\mathbf{n = 3 0})\end{array}$} \\
\cline { 2 - 6 } & Mean & SD & Mean & SD \\
\hline & 7.73 & 0.74 & 10.27 & 0.87 \\
\hline
\end{tabular}

Table-III. Comparison of length of hospital stay $(n=60)$

$P$ value $=0.0001$

Mean time of passage of first flatus in Chewing gum group was $49.97+1.69 \mathrm{hrs}$ and $89.17+2.07$ hrs in Control group, p value was 0.0001. (TableIV)

\begin{tabular}{|c|c|c|c|c|}
\hline $\begin{array}{c}\text { Time of } \\
\text { Passage of }\end{array}$ & \multicolumn{2}{|c|}{$\begin{array}{c}\text { Chewing Gum } \\
\text { Group }(\mathbf{n = 3 0})\end{array}$} & \multicolumn{3}{|c|}{$\begin{array}{c}\text { Control Group } \\
(\mathbf{n = 3 0})\end{array}$} \\
\hline $\begin{array}{c}\text { First Flatus } \\
\text { (hrs) }\end{array}$ & Mean & SD & Mean & SD \\
\hline & 49.97 & 1.69 & 89.17 & 2.07 \\
\hline
\end{tabular}

Table-IV. Comparison of time of passage of first flatus $(n=60)$

$P$ value $=0.0001$

Effect modifiers like age and gender was controlled by stratification. Post stratification independent sample t-test was applied. (Table-V to VIII)

\begin{tabular}{c|c|c|c|c|}
\hline $\begin{array}{c}\text { Time of } \\
\text { Length of } \\
\text { Hospital } \\
\text { stay }\end{array}$ & \multicolumn{2}{|c|}{$\begin{array}{c}\text { Chewing Gum } \\
\text { Group }(\mathbf{n = 3 0 )}\end{array}$} & \multicolumn{2}{|c|}{$\begin{array}{c}\text { Control Group } \\
(\mathbf{n = 3 0})\end{array}$} \\
\hline (Days) & Mean & SD & Mean & SD \\
\hline & 7.38 & 0.50 & 10.27 & 0.88 \\
\hline
\end{tabular}

Table-V1. Stratification for comparison of length of hospital stay with regards to age $(n=60)$ Age: $20-40$ years

$P$ value $=0.0001$

\begin{tabular}{|c|c|c|c|c|}
\hline $\begin{array}{c}\text { Time of } \\
\text { Length of } \\
\text { Hospital } \\
\text { stay }\end{array}$ & \multicolumn{2}{|c|}{$\begin{array}{c}\text { Chewing Gum } \\
\text { Group }(\mathbf{n = 3 0 )}\end{array}$} & \multicolumn{2}{|c|}{$\begin{array}{c}\text { Control Group } \\
(\mathbf{n = 3 0})\end{array}$} \\
\hline (Days) & Mean & SD & Mean & SD \\
\hline & 8.14 & 0.77 & 10.27 & 0.88 \\
\hline
\end{tabular}

Table-V2. Stratification for comparison of length of hospital stay with regards to age $(n=60)$ Age: 41-60 years. $P$ value $=0.0001$

\begin{tabular}{|c|c|c|c|c|}
\hline $\begin{array}{c}\text { Time of } \\
\text { Length of } \\
\text { Hospital stay } \\
\text { (days) }\end{array}$ & \multicolumn{2}{|c|}{$\begin{array}{c}\text { Chewing Gum } \\
\text { Group } \mathbf{( n = 3 0 )}\end{array}$} & \multicolumn{2}{|c|}{$\begin{array}{r}\text { Control Group } \\
\mathbf{( n = 3 0 )}\end{array}$} \\
\hline & Mean & SD & Mean & SD \\
\hline & 7.76 & 0.83 & 10.38 & 0.96 \\
\hline
\end{tabular}

Table-VI1. Stratification for comparison of length of hospital stay with regards to gender $(n=60)$ (Male) $P$ value $=0.0001$

\begin{tabular}{|c|c|c|c|c|}
\hline $\begin{array}{c}\text { Time of } \\
\text { Length of } \\
\text { Hospital } \\
\text { stay }\end{array}$ & \multicolumn{2}{|c|}{$\begin{array}{c}\text { Chewing Gum } \\
\text { Group }(\mathbf{n = 3 0 )}\end{array}$} & \multicolumn{3}{|c|}{$\begin{array}{c}\text { Control Group } \\
(\mathbf{n = 3 0})\end{array}$} \\
\hline (Days) & Mean & SD & Mean & SD \\
\hline & 7.69 & 0.63 & 10.14 & 0.77 \\
\hline
\end{tabular}

Table-VI2. Stratification for comparison of length of hospital stay with regards to gender (Female) $P$ value $=0.0001$

\section{Age: $20-40$ years}

\begin{tabular}{|c|c|c|c|c|}
\hline \multirow{3}{*}{$\begin{array}{l}\text { Time of } \\
\text { Passage of } \\
\text { First Flatus } \\
\quad \text { (hrs) }\end{array}$} & \multicolumn{2}{|c|}{$\begin{array}{l}\text { Chewing Gum } \\
\text { Group }(n=30)\end{array}$} & \multicolumn{2}{|c|}{$\begin{array}{l}\text { Control Group } \\
(n=30)\end{array}$} \\
\hline & Mean & SD & Mean & SD \\
\hline & 50.19 & 1.87 & 88.53 & 1.73 \\
\hline \multicolumn{5}{|c|}{$\begin{array}{l}\text { Table-VII. Stratification for comparison of time of } \\
\text { passage of first flatus with regards to age }(n=60) \\
\qquad \text { P value }=0.0001\end{array}$} \\
\hline
\end{tabular}

\section{Age: 41-60 years}

\begin{tabular}{|c|c|c|c|c|}
\hline \multirow{3}{*}{$\begin{array}{c}\text { Time of } \\
\text { Passage of } \\
\text { First Flatus } \\
\text { (hrs) }\end{array}$} & \multicolumn{2}{|c|}{$\begin{array}{l}\text { Chewing Gum } \\
\text { Group }(n=30)\end{array}$} & \multicolumn{2}{|c|}{$\begin{array}{l}\text { Control Group } \\
(n=30)\end{array}$} \\
\hline & Mean & SD & Mean & SD \\
\hline & 49.71 & 1.49 & 89.90 & 2.24 \\
\hline \multicolumn{5}{|c|}{$P$ value $=0.0001$} \\
\hline
\end{tabular}

\section{Male}

\begin{tabular}{|c|c|c|c|c|}
\hline \multirow{2}{*}{$\begin{array}{c}\text { Time of } \\
\text { Passage of }\end{array}$} & \multicolumn{2}{|c|}{$\begin{array}{c}\text { Chewing Gum } \\
\text { Group }(\mathbf{n = 3 0 )}\end{array}$} & \multicolumn{3}{|c|}{$\begin{array}{c}\text { Control Group } \\
\mathbf{( n = 3 0 )}\end{array}$} \\
\hline $\begin{array}{c}\text { First Flatus } \\
\text { (hrs) }\end{array}$ & Mean & SD & Mean & SD \\
\hline & 49.71 & 1.72 & 88.31 & 1.74 \\
\hline
\end{tabular}

Table-VIII. Stratification for comparison of time of passage of first flatus with regards to gender $(n=60)$ $P$ value $=0.0001$ 


\section{Female}

\begin{tabular}{|c|c|c|c|c|}
\hline \multirow{3}{*}{$\begin{array}{l}\text { Time of } \\
\text { Passage of } \\
\text { First Flatus } \\
\text { (hrs) }\end{array}$} & \multicolumn{2}{|c|}{$\begin{array}{l}\text { Chewing Gum } \\
\text { Group }(n=30)\end{array}$} & \multicolumn{2}{|c|}{$\begin{array}{l}\text { Control Group } \\
(n=30)\end{array}$} \\
\hline & Mean & SD & Mean & SD \\
\hline & 50.31 & 1.65 & 90.14 & 2.03 \\
\hline \multicolumn{5}{|c|}{$P$ value $=0.0001$} \\
\hline
\end{tabular}

\section{DISCUSSION}

Studies have reported that gums chewing after abdominal surgeries decrease postoperative ileus (POI); but very few studies are available on role of chewing gum after ileostomy reversal cases. This study was aimed to assess a better method with short length of hospital stay, lesser time of passage of first flatus and lesser time of appearance of bowel sound that will be offered to the patients in future.

In this study, mean length of hospital stay in Chewing gum group was $7.73+0.74$ days and $10.27+0.87$ days in Control group, $p$ value was 0.0001 , mean time of passage of first flatus in Chewing gum group was $49.97+1.69 \mathrm{hrs}$ and $89.17+2.07 \mathrm{hrs}$ in Control group, $\mathrm{p}$ value was 0.0001 . These findings are comparable with a study, where the length of hospital admission and treatment in gum chewing group was $7.63 \pm 1.47$ days while in control group it was $9.47 \pm 2.67$ days (p-value < 0.05), time of passage of first flatus in gum chewing group was $51.07 \pm 19.63$ hours while in control group it was $87.83 \pm 25.89$ hours (p-value < 0.05). ${ }^{10}$

In another study, length of hospital stay in gum chewing group was $6.31 \pm 5.47$ days while in control group it was $6.26 \pm 5.83$ days ( $p$-value $>0.05)$, time of passage of first flatus in gum chewing group was $71.64 \pm 78.42$ hours while in control group it was $82.11 \pm 52.31$ hours ( $p$-value $>0.05) \cdot{ }^{11}$ These findings do not match with our study.

In a Dutch study done on the role of gum chewing after abdominal surgery requiring gut mobilization, showed that about $27 \%$ cases improved and had lesser complications like ileus versus $48 \%$ control patients $(P=0.02)$. Most of the cases in the experimental group passed their first stool in 4 days $(P=0.006)$ and also most of the cases had their first flatus in the post-operative (in 2 days $(P=0.044)$, thus concluding that it is a safe practice to use chewing gum to prevent ileus in post-op patients. Duk $\mathrm{YH}$, et $\mathrm{al}^{12}$ also showed almost similar results in his study in which they studied laparoscopic colorectal cancer surgery patients.

Sanjay $\mathrm{M}$ et al. ${ }^{13}$ also studied the role of gum chewing on patients of small bowel anastomosis i.e ileostomy closure in cases of typhoid perforation and reported that even in cases requiring breaking up of adhesions with further bowel handling also improved with the use of gum chewing technique. The positive results were also got in some other researches.

Similarly, Shin YJ, et al. ${ }^{14}$ reported, after studying the role of chewing gum in cases of open-liver resection and liver cancer patients, an active recovery in the bowel movement and also decreased the xerostomia grade.

Kazuyoshi T et al. ${ }^{15}$ reported that in the post-op bowel movement and activity improved with gum chewing in patients of abdominal aortic surgery. Flatus was passed on earlier in experimental group compared to the control group $(P=0.0004)$ and oral intake started earlier in cases versus controls $(P=0.023)$.

Gum chewing enhanced early recovery of bowel function following transperitoneal abdominal aortic surgery. Finally, the results of our study in accordance to the above supported studies justifying the hypothesis that "Gum chewing is better than standard post-operative care in patients undergoing elective surgery for ileostomy closure done for typhoid ileal perforation in terms of mean length of hospital stay and mean time of passage of first flatus".

\section{CONCLUSION}

We concluded that post-operative gum chewing with standard post-operative care in patients undergoing elective surgery for ileostomy closure done for typhoid ileal perforation in terms of mean length of hospital stay and mean time of 
passage of first flatus is significantly better than those without gum chewing.

\section{CONFLICT OF INTEREST}

All authors have declared that there is no conflict of interest.

\section{LIMIATATION OF STUDY}

This study was conducted in a single tertiary hospital in a one city. This trial should be done on a larger scale and larger data is required. Further controlled trials should be done to see any complications related to chewing gum.

Copyright@ 10 Oct, 2019.

\section{REFERENCES}

1. Contini $S$. Typhoid intestinal perforation in developing countries: Still unavoidable death? World $\mathrm{J}$ gastroenterol. 2017; 23:1925-31.

2. Chaudhary P, Nabi I, Ranjan G, Tiwari AK, Kimar S, Kapur A, et al. Prospective analysis of indications and early complications of emergency temporary loop ileostomies for perforation peritonitis. Ann Gastroenterol. 2015; 28:135-40.

3. Musters GD, AtemaJJ, Van Westreenen HL, Buskens CJ, Bemelman WA, Tanis PJ. lleostomy closure by colorectal surgeons results in less major morbidity: Results from an institutional change in practice and awareness. Int J Colorectal Dis 2016; 31:661-7.

4. Sier MF, Van Gelder L, Ubbink DT, Bemelman WA, Oostenbroek RJ. Factors affecting timing of closure and non-reversal of temporary ileostomies. IntJ Colorectal Dis 2015; 30:1185-92.

5. Ge W, Chen G, Ding Y. Effect of chewing gum on the postoperative recovery of gastrointestinal function. Int J Clin Exp Med. 2015; 8:11936-42.

6. Marwah S, Singla S, Tinna P. Role of gum chewing on the duration of postoperative ileus following ileostomy closure done for typhoid ileal perforation: A prospective randomized trial. Saudi J Gastroenterol. 2012; 18:111-7.
7. Yang $Y$, Zuo H, Li Z, Qin Y, Mo X, Huang M, et al. Comparison of efficacy of simo decoction and acupuncture or chewing gum alone on postoperative ileus in colorectal cancer resection: A randomized trial. Sci Rep. 2017; 7:37826.

8. Keller D, Stein SL. Facilitating return of bowel function after colorectal surgery: Alvimopan and gum chewing. Clin Colon Rectal Surg. 2013; 26:186-90.

9. Atikson C, Penfold CM, Ness AR, Longman RJ, Thomas SJ, Hollingworth W, et al. Randomized clinical trial of postoperative chewing gum versus standard care after colorectal resection. $\mathrm{Br} J$ Surg. 2016; 103:96270.

10. TopcuSY, Oztekin SD. Effect of gum chewing on reducing postoperative ileus and recovery after colorectal surgery: A randomised controlled trial. Complement TherClinPract. 2016; 23:21-5.

11. Forrester DA, Doyle-Munoz J, McTigue T, D’Andrea $S$, Natale-Ryan $A$. The efficacy of gum chewing in reducing postoperative ileus: A multisite randomized controlled trial. J Wound Ostomy Continence Nurs. 2014; 41:227-32.

12. DukYH, Kim HY, Kim JH, Lee IG, Kim JK, Oh ST, Lee YS. Effect of gum chewing on the recovery from laparoscopic colorectal cancer surgery. Ann Coloproctol. 2013; 29:248-251.

13. Sanjay M, Marwah S, Singla S, Tinna P. Role of gum chewing on the duration of postoperative ileus following ileostomy closure done for typhoid ileal perforation: A prospective randomized trial. Saudi J Gastroenterol. 2012; 18:111-7.

14. Shin YJ, Jang SY, JuEY, Kim DE, Kim JH, Kim YH, Son $M$, Jang $M$, JeongJH, Kim KS. First flatus time and xerostomia associated with gum-chewing after liver resection. J Clin Nurs. 2010; 21:2188-92.

15. Kazuyoshi T, Takagi K, Teshima H, Arinaga K, Yoshikawa K, Hori H, Kashikie H, Nakamura K. Gum chewing enhances early recovery of bowel function following transperitoneal abdominal aortic surgery. Surg Today. 2012; 42:759-64. 


\section{AUTHORSHIP AND CONTRIBUTION DECLARATION}

\begin{tabular}{|c|c|c|c|}
\hline Sr. \# & Author(s) Full Name & Contribution to the paper & Author(s) Signature \\
\hline 1 & Muhammad Kamran & $\begin{array}{l}\text { Write up of contents, Data } \\
\text { collection, Analysis, Compilation } \\
\text { of results. }\end{array}$ & \\
\hline 2 & Shahbaz Ahmad & $\begin{array}{l}\text { Literature review, write up of } \\
\text { contents interpretation. }\end{array}$ & \\
\hline 3 & M. Faheem Anwer & $\begin{array}{l}\text { Literature review, write up of } \\
\text { contents interpretation. }\end{array}$ & \\
\hline 4 & M. Hasan Anwaar & $\begin{array}{l}\text { Data collection, Write up of } \\
\text { contents, Analysis. }\end{array}$ & \\
\hline 5 & Muhammad Asif & $\begin{array}{l}\text { Data collection, Referencing, } \\
\text { Interpretation. }\end{array}$ & \\
\hline 6 & Rabail Rana & $\begin{array}{l}\text { Literature Review, References, } \\
\text { Compilation of resutls. }\end{array}$ & \\
\hline
\end{tabular}

